\title{
The reproduction viability of Indonesian endemic fish Oryzias marmoratus (Aurich, 1935) fed by Spirulina
}

\author{
Djamhuriyah S. Said ${ }^{1, *}$, Novi Mayasari ${ }^{1}$, Awalina Satya ${ }^{1}$, Tjandra Chrismadha ${ }^{1}$ Dwi \\ Febrianti ${ }^{1}$, \\ ${ }^{1}$ Research Center for Limnology, National Research and Innovation Agency (BRIN), Komplek CSC- \\ BG. J1 Raya Bogor KM 46 Cibinong, Bogor, Indonesia 16911
}

\begin{abstract}
Oryzias marmoratus is one of the ornamental aquarium fish species that live endemic to Towuti Lake, South of Sulawesi, Indonesia. However, the fish has been categorized as near threatened by IUCN. A current report showed the fish could be cultivated. This research aims to improve the reproduction quality in cultivation by using artificial feed containing Spirulina $(\mathrm{A}=0, \mathrm{~B}=3$, and $\mathrm{C}=6) \%$ dry weight. The study was conducted with two replications using an aquarium $(80 \times 40 \times 40 \mathrm{~cm})$ for 40 days (October-December 2020) at Research Center for LimnologyLIPI. Each aquarium contains 21 broodstock (female: male $=2: 1$ ). Observation parameters are the total number of spawning/ToS (time), ovulated eggs number/OEN, fertilization ability/FA (\%), hatching ability/HA (\%), number of larvae/NoL, the egg of incubation time/EIT (day), survival of larvae seven days old after hatching/SR7 (\%). Based on descriptive analysis, the use of feed $\mathrm{C}$ (containing $6 \%$ Spirulina) produced the highest values of ToS, OEN, \%HA, NoL, and SR7 (\%) were ten times; 89 eggs; 89 larvae, 100\%; and $98.89 \pm 3.51 \%$ respectively. Spirulina could increase the reproduction viability and is presumed to enhance feed efficiency of Oryzias marmoratus, but the optimum levels have not been obtained.
\end{abstract}

\section{Introduction}

Oryzias marmoratus with the famous name Marmorated medaka is one species of the Medaka group that belongs to the Subfamilia Oryziinae, family Adrianichthyidae. These benthopelagic and schooling fish is endemic on Towuti Lake and other lakes in the Lakes of Malili group, South of Sulawesi, Indonesia [1,2]. Adult fish has a beautiful color on the fins, and on both sides of their small body sometimes look transparent and sometimes olivegreen color with a regularly black spot distributed like marble (Fig.1). Therefore $O$. marmoratus could be used for aquarium fish or an experimental material for various research like the other Medakas [1, 3-6]. In addition, the fish has a function as a protein source for the local communities of Lake Towuti, and the fishing activity of the fish is very

*Corresponding author: djamhuriyah@limnologi.lipi.go.id 
intensive [7, 8]. According to IUCN information, the fish has the conservation status as vulnerable or Near Threatened species [9, 10]. The condition can be anticipated by conservation efforts necessary to carry out both in-situ or ex-situ development (domestication) or cultivation. A current report that $O$. marmoratus can survive, adapt and develop in ex-situ habitats or cultivation $[6,11]$. A further step is needed to improve the quality of the fish. Quality improvement can be carried out in several methods, including maintenance environment of rearing, both the physical-chemical environment of the media cultivation and treatment of the feed given, or other manipulations. Feed treatment can be done by adding certain substances to the feed given. Spirulina is one of the additives materials that can be applied in the manipulation of fish feed.

Spirulina is a single/colonized type of blue-green algae (micro-algae) that contains high protein. Besides, it also contains chlorophyll, carotenoids, phycobilin pigments (phycocyanin and phycoerythrin), essential acids, various vitamins, minerals [12-15]. The nutrient contents of Spirulina are excellent as a source of food, health, and cosmetics of humans, as well as feed. In an aquaculture system, Spirulina is applied to fish feed ingredients to improve the quality of fish, such as reproduction as well as growth appearance, survival, taste, or the color performance of ornamental fish. Microalgae have an essential role in the aquaculture system. The use of microalgae can be indirectly or directly related to the impact of nutrients on various aquaculture organisms [16].

Research on the uses of Spirulina in feed for ornamental fish, consumption fish or shrimp has been widely carried out such as chiclid, koi, guppies, Tricogaster, goldfish, carp, tilapia, catfish, or giant prawns [17 - 24], and others. In general, the overall use of Spirulina has a good effect on these commodities such as color appearance, taste, growth, reproduction, and feed conversion. A trial of feed containing Spirulina on increasing reproduction of the endemic fish $O$. marmoraus has not been reported. It is expected that the addition of Spirulina on the feed will increase the viability of reproduction of $O$. marmoratus. This research aims to study the performance of reproductive viability of $O$. marmoratus fish fed by Spirulina and obtain information on the optimum dose of Spirulina in feed for the highest reproduction viability of the fish.

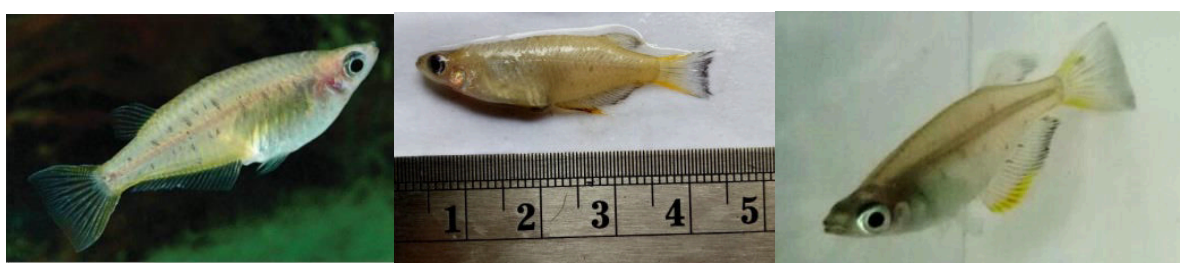

Fig. 1. Oryzias marmoratus (Photo: DSSaid)

\section{Materials and methods}

\subsection{Preparation of broodstock and rearing aquarium}

The study was conducted for 40 days (October-December 2020) with two replications. The number of broodstock and replications used in this research were adjusted to the number of broodstock available. The broodstock used was about 11 months old, a collection of Research Center for Limnology-LIPI Laboratory. Spawning was carried out by mass spawning, of each 21 broodstock a ratio of female: male equal to 2:1 (14 female and 7 male). The sex ratio of the fish in this research refers to [6]. The broodstock was measured and then reared in an aquarium measuring $80 \times 40 \times 40 \mathrm{~cm}$, filled with a height of $25 \mathrm{~cm}$, and 
equipped with an aeration system. The fish were acclimatized for one week to this rearing system.

\subsection{Feed preparation and feeding}

The primary feed used was commercial feed (pellets). At the same time, the Spirulina added to this feed was dried powder Spirulina cultured from the Planktonology Laboratory, $\mathrm{RC}$ for Limnology, Indonesian Institute of Sciences (LIPI). Commercial feed is ground and then regenerated using a feed-making machine. Three categories of feed were made, namely Feed A (primary feed, 0\% Spirulina/control), Feed B was (basic feed $+3 \%$ Spirulina per $\mathrm{kg}$ of feed), and Feed $\mathrm{C}$ (basic feed $+6 \%$ Spirulina per kg of feed). After re-pelleting, the feed is dried in an open room without direct sunlight. Then the feed formed is reduced in size using a blender and then filtered to get feed according to the size of the fish mouth. The amount of feed for each aquarium was weighed $(\mathrm{g})$. The observation fish were fed $a d$ libittum in the morning and evening. After 40 days of observation, the remaining feed was weighed. The amount of feed consumed (Table 2) is the result of subtraction between the initial feed and the last feed.

\subsection{Observation of reproductive viability}

Observation of reproductive viability refers to $[6,24]$. The dark color of plastic material (raffia) was used as an artificial substrate to keep the newly laid ovulated eggs. The observation was carried out daily for 40 days. The eggs' substrate was moved to a bit of aquarium $(25 \times 25 \times 20) \mathrm{cm}$ for hatching and larval rearing until seven days old. These aquariums are also housed in the broodstock room. The viability of reproduction observed consists of the total of spawning (ToS), the ovulated eggs number (OEN), fertilization ability (FA/\%), hatching ability (HA/\%), eggs incubation time to hatch (EIT/days), some larvae $(\mathrm{NoL})$, Rasio of hatching to spawning (\%) and survival of the larvae for seven days old after hatching (SR7) (\%) (Table 1). Data analysis is done descriptively.

Table 1. Parameters of reproduction viability $[6,25]$.

\begin{tabular}{|c|c|c|}
\hline No. & Parameters of viability & Explanation \\
\hline 1 & Total of Spawning/ToS (time) & Total Number of spawning for 40 days \\
\hline 2 & $\begin{array}{l}\text { Ovulated Eggs Number/ OEN } \\
\text { (egg) }\end{array}$ & Total Amount of ovulated eggs of all spawning \\
\hline 3 & Fertilization Ability/FA (\%) & The ratio of fertilized eggs to total ovulated eggs \\
\hline 4 & Number of Hatching/NH (time) & $\begin{array}{l}\text { The total of hatchings that took place from the number } \\
\text { of the spawning }\end{array}$ \\
\hline 5 & $\begin{array}{l}\text { Ratio of Hatching to Total } \\
\text { Spawning/NH of ToS }(\%)\end{array}$ & $\begin{array}{l}\text { The percentage of the amount of hatching to the total } \\
\text { spawning has occurred }\end{array}$ \\
\hline 6 & Hatching Ability/HA (\%) & The percentage of hatched larvae to total fertilized eggs \\
\hline 7 & Number of Larvae/NoL (larvae) & Some larvae that have hatched \\
\hline 8 & Egg of Incubation Time/EIT (day) & Total time (days) required from spawning to hatching \\
\hline 9 & $\begin{array}{l}\text { Survival } 7 \text { days old after } \\
\text { hatching/SR7 }(\%)\end{array}$ & $\begin{array}{l}\text { The ratio of larval survival at seven days to the initial } \\
\text { number of larvae }\end{array}$ \\
\hline
\end{tabular}




\section{Result}

The average size of male and female broodstock and the amount of feed consumed in each treatment are shown in Table 2 . The reproduction viability values of O. marmoratus are shown in Table 3.

Table 2. Broodstock size of $O$. marmoratus and the amount of feed consumed.

\begin{tabular}{|c|c|c|c|c|c|c|c|c|c|}
\hline \multirow[b]{3}{*}{ Sex } & \multicolumn{9}{|c|}{ The broodstocks size and amount of feed of each treatment } \\
\hline & \multicolumn{3}{|c|}{$\mathbf{A}$} & \multicolumn{3}{|c|}{ B } & \multicolumn{3}{|c|}{$\mathbf{C}$} \\
\hline & $\begin{array}{c}\text { Length } \\
(\mathrm{mm})\end{array}$ & $\begin{array}{c}\text { Weight } \\
\text { (g) }\end{array}$ & $\begin{array}{c}\sum \text { Feed } \\
(\mathrm{g})\end{array}$ & $\begin{array}{c}\text { Length } \\
(\mathrm{mm})\end{array}$ & $\begin{array}{c}\text { Weight } \\
(\mathrm{g})\end{array}$ & $\begin{array}{c}\sum \text { Feed } \\
(\mathrm{g})\end{array}$ & $\begin{array}{c}\text { Length } \\
\text { (mm) }\end{array}$ & $\begin{array}{c}\text { Weight } \\
(\mathrm{g})\end{array}$ & $\begin{array}{c}\sum \text { Feed } \\
(\mathrm{g})\end{array}$ \\
\hline$\hat{\sigma}$ & 44.43 & 0.71 & & 42.43 & 0.85 & & 40.4 & 0.73 & \\
\hline $\mathrm{Sd}$ & 3.41 & 0.18 & & 2.76 & 0.16 & & 4.28 & 0.11 & \\
\hline Range & $38-48$ & $0.56-0.99$ & & $40-48$ & $0.60-0.99$ & & $38-48$ & $0.60-0.89$ & \\
\hline & & & 18.84 & & & 18.18 & & & 16.88 \\
\hline q & 40.0 & 0.66 & & 41.0 & 0.70 & & 40.24 & 0.65 & \\
\hline $\mathrm{Sd}$ & 2.37 & 0.12 & & 3.77 & 0.09 & & 3.21 & 0.03 & \\
\hline Range & $38-46$ & $0.55-0.88$ & & $36-48$ & $0.60-0.88$ & & $37-46$ & $0.60-0.73$ & \\
\hline
\end{tabular}

Table 3 shows that $O$. marmoratus fed with Spirulina content of $6 \%$ (C treatment) has the highest ranking on 6 of the nine observed viability parameters (Table 3). Those were produced the highest of ToS, OEE, NH, NoL, HA, and SR7 compared to other feed treatments. The FA and \% Rasio hatching of spawning $(\mathrm{NH}$ of ToS) value has the same value, which is $100 \%$ each, while the EIT value (day) is longer than the others.

Table 3. The value of reproduction viability of O.marmoratus for 40 days.

\begin{tabular}{|c|l|c|c|c|c|c|c|}
\hline \multirow{2}{*}{ No } & \multirow{2}{*}{$\begin{array}{c}\text { Parameters of } \\
\text { viability }\end{array}$} & \multicolumn{4}{|c|}{ Feed treatment } & \multicolumn{2}{c|}{$\begin{array}{c}\text { The rank of the value of } \\
\text { treatment }\end{array}$} \\
\cline { 3 - 8 } & & $\mathrm{A}$ & $\mathrm{B}$ & $\mathrm{C}$ & $\mathrm{A}$ & $\mathrm{B}$ & $\mathrm{C}$ \\
\hline 1 & ToS (time) & $5.5 \pm 0.71$ & $8.5 \pm 0.71$ & $10 \pm 0.0$ & 3 & 2 & 1 \\
\hline 2 & OEN (eggs) & $44.5 \pm 7.78$ & $66.5 \pm 2.12$ & $89 \pm 2.83$ & 3 & 2 & 1 \\
\hline 3 & FA (\%) & 100 & 100 & 100 & $\mathrm{R}$ & $\mathrm{R}$ & $\mathrm{R}$ \\
\hline 4 & NH (time) & $5.5 \pm 0.71$ & $8.5 \pm 0.71$ & $10 \pm 0.0$ & 3 & 2 & 1 \\
\hline 5 & NH of ToS (\%) & 100 & 100 & 100 & $\mathrm{R}$ & $\mathrm{R}$ & $\mathrm{R}$ \\
\hline 6 & HA (\%) & $86.87 \pm 13.65$ & $92.71 \pm 13.68$ & $100 \pm 0$ & 3 & 2 & 1 \\
\hline 7 & NoL (larvae) & $39 \pm 6.75$ & $61.6 \pm 1.97$ & $89 \pm 2.83$ & 3 & 2 & 1 \\
\hline 8 & EIT (days) & $7.60 \pm 1.82$ & $7.63 \pm 1.30$ & $7.80 \pm 1.87$ & 1 & 2 & 3 \\
\hline 9 & SR7 (\%) & $96 \pm 8.94$ & $98.44 \pm 4.42$ & $98.89 \pm 3.51$ & 3 & 2 & 1 \\
\hline
\end{tabular}

$R=$ have the same values

\section{Discussion}

The length average of broodstock used in the three treatments was almost the same size, about $40 \mathrm{~mm}$ (Table 2). These sizes are similar to the size of an adult $O$. marmoratus has used by [6]. The size of the male is more significant than the female. According to [1, 3, 4, 6] that $O$. marmoratus is about $4-5 \mathrm{~cm}$ in length, and the female is smaller than males.

The fish of $\mathrm{C}$ treatment consumed the least amount of feed compared to others that which was $16.88 \mathrm{~g}$, followed by treatments B (18.18 g) and A (18.84 g) (Table 2). On the other hand, the number of ToS and OEN in treatment $C$ was mainly followed by treatment $\mathrm{B}$ then A (Table 3). Those number shows that the amount of feed consumed is not directly 
proportional to the number of spawning eggs produced. These data indicate that the use of Spirulina in feed can increase the feed efficiency of $O$. marmoratus. Inline to [18, 26, 27] results that Poecilia reticulata, Carassius auratus, and Clarias gariepinus fed a diet with a higher Spirulina content had a good effect on the value of feed conversion and growth.

Broodstock size in $\mathrm{C}$ treatment was relatively smaller than in $\mathrm{B}$ treatment and almost the same as the A treatment (control). However, the ToS, OEN of $\mathrm{C}$ treatment was more than B and A treatment. The ToS and OEN in treatment $\mathrm{C}$ were also higher than the results of [6], which showed that $O$ marmoratus broodstock size was 43,172 $\pm 4,997$ (34-52) mm produced only seven times of ToS in 37 days and 55 (25-125) ovulated eggs. Generally, a larger body size had higher fecundity [28]. The results of previous studies also showed the positive correlation of body weight with fecundity like in Puntius ticto [29], Neolissochilus sumatranus, and Tor douronensis [30]. This study also showed that feed containing higher Spirulina had affected increased fecundity (shown by OEN) and spawning number (ToS) of O. marmoratus. According to [14], all yellowtail chiclid fed with Spirulina diets was significantly higher on the production of total eggs than the fish fed diet control. So that indicated that the inclusion of dietary Spirulina meal has the potential to enhance reproduction, the performance of growth, and the coloration of the fish. Similarly, [31] reported that feeding containing $8 \%$ of Spirulina has better performance on growth, fertility, gonadosomatic Index, gonadal quality, and coloration on ornamental fish Xiphoporus helleri. This phenomenon shows that feed containing Spirulina has the same effect on O. marmoratus.

In this study, it was seen that the FA (\%) and the ratio of $\mathrm{NH}$ to ToS (\%) values for all treatments had the same value $(100 \%)$ (Table 3$)$. The result of [6] that as many as 45 broodstock $O$. marmoratus (male: female $=1: 2$ ) produced a spawning frequency of 7 times 37 days. All samples have FA and Rasio of NH to ToS, which are $100 \%$ each. The FA and ratio of $\mathrm{NH}$ to ToS values of each $100 \%$ indicates that all eggs produced by females are fertilized by the sperm of males, which results in good quality embryos which all hatch to produce larvae. This ratio confirms that the sex ratio for the optimum reproduction of $O$. marmoratus is male: female $=1: 2$.

The HR and SR 7 in C treatment were the highest that are 100 and $98.89 \pm 3.51 \%$, respectively. According to [14] that yellowtail chiclid (Pseudotropheus acei) fed with Spirulina diets was significantly higher on hatching rate (\%), and that was increased the survival and growth rate of Clarias gariepinus [27] and enhanced the production of progeny and growth performance of Kenya cichlid (Maylandia lombardoi) [32]. This value shows that Spirulina inclusion in the feed improved its growth and survival rate, growth performance, progeny production, and skin coloration.

The EIP value (days) in treatment C $(7.80 \pm 1.87)$ was slightly longer than the EIP value of B $(7.63 \pm 1.3)$ and A treatments $(7.60 \pm 1.82)$ (Table 3). Increased content of Spirulina in the feed, there is a tendency to increase the EIP time. Feed containing Spirulina presumed affects the hatching process of the eggs (embryos). It is presumed that the mineral content (such as Calcium) of Spirulina has strengthened the condition of the embryo chorion, namely the permeable protective layer of the embryo. The research results [33] in poultry that the addition of Calcium to the feed has strengthened the quality of poultry eggs, and [34] was reported that the addition of Calcium in the rearing water affects the hatching process of hybrid channel catfish eggs. Calcium provides specific needs in the embryogenesis process of fish [34].

In general, the results of this study indicate that the feed with $6 \%$ of Spirulina has enhanced the reproduction viability value than the 3\% Spirulina treatment and control on the number of spawning, number of eggs, hatching ability, number of larvae produced, and survival rate of larvae seven days old after hatching. This study also showed that Spirulina in the feed had increased the feed efficiency of $O$. marmoratus. 
Spirulina is micro-algae that contains high protein (up to $70 \%$ dry weight) amino acids, lipids, fatty acids, photosynthetic pigments, carotenoids, various vitamins, minerals, and other ingredients $[15,26]$ that are essential for, i.e., reproduction development and growth performance. The results of this research indicated that the fish are in good health condition. These conditions indicate that the fish get complete nutrition from the feed given. The protein content in the feed provides the best feed quality so that protein is used for reproduction, somatic growth, and feed efficiency. According to [35], the protein, fatty acids, and lipids of Spirulina are the main constituents of egg yolk, and essential fatty acids content provide energy for fish spawning. The rate of vitellogenesis, development, and maturation of oocytes are affected by protein and essential fatty acid, and B vitamin from Spirulina will improve the performance of fish reproduction [35].

\section{Conclusion}

Spirulina in feed up to $6 \%$ has increased reproduction viability in the components of a total number of spawning, number of ovulated eggs, hatching ability, number of larvae produced, and survival of larvae seven days old after hatching. The optimal level of Spirulina in feed has not been obtained to increase the highest reproduction viability of $O$. marmoratus. There was also a tendency that the Spirulina had increased the feed efficiency of O. marmoratus.

\section{Acknowledgments}

This research was conducted at Aquatic Laboratory, Research Center for Limnology-LIPI, funded by the MALSAI, LIPI Program 2020. Special thanks to Mr. Ismail, Mr. Heri, and Miss Aidina Kh Hanifah for their help.

\section{References}

1. M. Kottelat, A.J. Whitten, S.N. Kartikasari, S. Wirjoatmodjo, Freshwater fishes of western Indonesia and Sulawesi (Periplus, Jakarta,1993) (in Bahasa Indonesia)

2. H. Dahruddin, Fauna Indones. 11, 2 (2012)

3. D.S. Said, Technical Activities List of 2005 Budget Executors (Pusat Penelitian Limnologi LIPI, Bogor, Indonesia 2005) (in Bahasa Indonesia)

4. D.S.Said, Hidayat, 101 Indonesian Freshwater Ornamental Fish (in Bahasa Indonesia) (LIPI Press, Jakarta 2015)

5. M.R. Fahmi, A. B. Prasetyo, R. Vidikusuma., Prosiding Seminar Nasional Ikan keVIII, 227-245 (2016)

6. D S. Said, N. Mayasari, IOP Conf. Ser. Earth and Environ. Sci.744 (2021)

7. S. Husni. Nasution, Proc. Intl. Symp. 39-46 (2006)

8. H.S. Makmur, Samuel, D.W.H Tjahjo, D. Octaviani, In Z. I. Azwar et al. Archipelago ornamental fish (in Bahasa Indonesia) (Pusat Riset Perikanan Budidaya Departemen Kelautan dan Perikanan, Jakarta, 2007)

9. M. Kottelat, Oryzias marmoratus the IUCN Red List of threatened species 1996, https://dx.doi.org/10.2305/IUCN.UK.1996.RLTS.T15574A4835817.en (1996)

10. D. Lumbantobing, Oryzias marmoratus the IUCN red list of threatened species 2019, https://dx.doi.org/10.2305/IUCN.UK.2019-2.RLTS.T15574A90980644.en (2019)

11. D.S. Said, N. Mayasari, Prosiding Seminar Nasinal Ikan ke 10 dan Kongres MII ke 5, 527-539 (2018) 
12. Widianingsih, A. Ridho, R. Hartati, Harmoko, J. Ilmu Kelaut, 13, 3 (2008)

13. I. Setyaningsih, A.T. Saputra, Uju, J. Pengolahan Hasil Perikanan Indonesia 14, 1 (2011)

14. B. Guroy, I. Sahin, S. Mantoglu, S.Kayali, Aquac. Int. 20, 869-878 (2012)

15. D. Liestianty, I. Rodianawati, R.A. Arfah, A. Assa, Patimah, Sundari, Muliadi, IOP Conf. Ser. $\mathbf{5 0 9}$ (2019)

16. N.B. Halima, J. Biochem. Biotech. 1, 11-13 (2017)

17. L. Gouveia, P. Rema,O. Pereira, J. Empis, Aquac. Nutr. 9, 123-129 (2003).

18. S. Dernekbasi, H. Unal, I. Karayucel, O. Aral, J. Anim. and Vet. Adv. 9, 9 (2010)

19. K. Noviyanti, Tarsim, H.W. Maharani. e-J. Rekayasa Teknol. Budid. Perairan 3, 2 (2015).

20. D.M. Malini, T.K.P. Dewi, R. Agustin, J. Pro-Life 5, 579-588 (2018)

21. R. Zulmi, Sumantriyadi, Supriyadi, J. Ilmu-ilmu Perikan. Budid. Perair. 13, 1 (2018)

22. S.Bakshi, S. Behera, Sh. Saha, A. Mandal, A. Das, D. Bhakta, A. Mondal, P. Patra, J. Entomol. and Zool. Stud. 6, 1 (2018)

23. El J.B. Dohaish, M. Al Dhahri, H. Omar, J. Am. Sci. 14, 10 (2018)

24. N. Nazhiroh, Mulyana, F.S.Mumpuni. J. Mina Sains, 5, 1 (2019)

25. D.S. Said, O. Carman, Abinawanto, Proc. of JSPS-DGHE Intl. Symp. Suistanable Fisheries in Asia in the New Millenia, 280-283 (2000)

26. M. Christwardana, N. Hadiyanto, J. Aplikasi Tek. Pangan 2, 1 (2013)

27. P.D.L.C. De Chavez, R.B. Bolivar, AACL Bioflux 11, 2 (2018)

28. E. Woynarovich, L. Horvart, The artificial propagation of warm water finfishes. A manual for Extention (FAO Fish. Tech. Paper, Rome 1980).

29. M.Y. Hossain, M.M. Rahman, E.M. Abdallah, Sains Malays. 41, 7 (2012)

30. D.S. Said, N. Mayasari, D. Febrianti, Dolok Bonan Batak Fish, Samosir Regency, North Sumatra (Mirra Buana Media, Yogyakarta, Indonesia, 2020)

31. R. James, K. Sampath, R. Thangarathinam, I. Vasudevan, The Isr. J. of Aquaculture Bamidgeh 58, 2 (2006)

32. O. Karadal, De. Güroy, G. Türkmen, Aquac. Int. 25, 121-134 (2017)

33. W. F. Pepper, J. D. Summers, J. D. Mcconachie, Poult. Sci. 47, 1 (1968)

34. N. G. Chatakondi, J. World Aquacult. Soc. 50, 3 (2018)

35. O. M. Wahbi, Y.Sangak, J. Biol. Sci. 17, 305-311 (2017) 